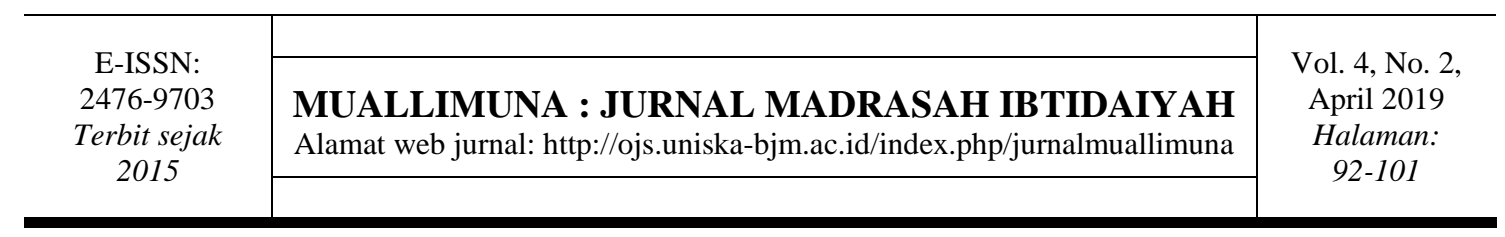

\title{
MENINGKATKAN KETERAMPILAN BERPIKIR KRITIS DAN GEMAR MEMBACA PESERTA DIDIK MELALUI MODEL PREDICT OBSERVE EXPLAIN BERBASIS LITERASI
}

\author{
Anggit Fathiara', Badarudin², Aji Heru Muslim ${ }^{3}$ \\ 1,2,3 PGSD, Universitas Muhammadiyah Purwokerto \\ 19anggitfathiaraa@gmail.com, ${ }^{2}$ badarudin@gmail.com, ${ }^{3}$ ajiherumuslim@gmail.com
}

\begin{abstract}
ABSTRAK: Latar belakang penelitian ini adalah rendahnya keterampilan berpikir kritis dan sikap gemar membaca peserta didik. Penelitian ini bertujuan untuk meningkatkan keterampilan berpikir kritis dan sikap gemar membaca peserta didik melalui model pembelajaran Predict Observe Explain (POE) berbasis literasi. Penelitian ini terdiri dari tahapan perencanaan, tindakan, observasi dan refleksi. Subjek penelitian ini adalah peserta didik Kelas IV A SDN 4 Kotayasa yang berjumlah 26 peserta didik yang terdiri dari 12 peserta didik laki-laki dan 14 peserta didik perempuan. Alat pengumpulan data menggunakan tes keterampilan berpikir kritis, lembar aktivitas guru, lembar aktivitas peserta didik, lembar observasi sikap gemar membaca peserta didik serta lembar skala sikap gemar membaca peserta didik. Hasil peningkatan yang terjadi dapat dilihat pada setiap siklusnya. Hasil penelitian ini menunjukkan bahwa penggunaan model pembelajaran Predict Observe Explain (POE) berbasis literasi dapat meningkatkan keterampilan berpikir kritis dan sikap gemar membaca peserta didik pada tema 7 Indahnya Keragaman di Negeriku di kelas IV A SDN 4 Kotayasa, Kecamatan Sumbang, Banyumas.
\end{abstract}

Kata Kunci : Berpikir Kritis; Gemar Membaca; Predict Observe Explain; POE; Literasi

\section{IMPROVING CRITICAL THINKING SKILLS AND LIKE TO READ OF STUDENTS THROUGH PREDICT OBSERVE EXPLAIN MODELS BASED ON LITERACY}

\begin{abstract}
The background of this study is the low level of critical thinking skills and the reading interest's students. This study aims to improve critical thinking skills and the reading interest's students through literacy-based Predict Observe Explain (POE) learning models. This research consists of stages of planning, action, observation and reflection. The subjects of this study were the $4^{\text {th }}$ A grade students of SDN4 Kotayasawhich amount to 26 students consisting of 12 boy and 14 girl. The tools that used for collecting data are tests of critical thinking skills, teacher activity sheets, student activity sheets, observation sheets, attitudes to reading students and scale sheets of attitude to love reading students. The results of the improvements that occur can be seen in each cycle. The results of this study indicate that the use of a literacy based Predict Observe Explain (POE) model can improve the critical thinking skills and the reading attitude of students in Theme 7 "The Beauty of Diversity in My Country"in $4^{\text {th }}$ A grade SDN 4 Kotayasa, Sumbang Sub-District, Banyumas District.
\end{abstract}

Keywords: Critical thinking; Like to read; Predict Observe Explain; POE; Literacy 


\section{PENDAHULUAN}

Kegiatan gemar membaca merupakan salah satu dari 18 nilai karakter yang harus dimiliki oleh peserta didik. Menurut Kementrian Pendidikan Nasional (Kemendiknas) terdapat 18 nilai karakter yang harus dirumuskan salah satunya adalah gemar membaca. Kegiatan gemar membaca sangat membantu dan menunjang kegiatan pembelajaran, dengan membaca peserta didik akan terbuka pikirannya, sehingga peserta didik dapat memperoleh pengetahuan dan wawasan yang luas.

Gemar membaca adalah suatu pola kebiasaan seseorang untuk melakukan aktivitas membaca dari berbagai bacaan dan tidak hanya dari satu sumber saja yang bertujuan untuk memperoleh informasi secara luas dan merupakan salah satu cara untuk memperoleh ilmu. Rianti (2015: 16-25) mengemukakan bahwa manfaat gemar membaca antara lain adalah: 1) Memperluas pengetahuan. 2) Memberikan kekuatan pada daya ingat. 3) Meningkatkan kosakata. 4) Menumbuhkan dan meningkatkan rasa kepedulian. 5) Mencerahkan hari. 6) Membangun rasa percaya diri. 7) Meningkatkan kreatifitas. 8) Meningkatkan kedisiplinan.

Salah satu faktor yang mempengaruhi sikap gemar membaca adalah keterampilan berpikir kritis. Sikap gemar membaca dapat membangun peserta didik untuk meningkatkan keterampilan berpikir kritis, karena dengan sikap gemar membaca peserta didik akan dihadapkan dengan beberapa permasalahan yang ditemukan setelah membaca dan menyimak sebuah cerita atau informasi. Dengan permasalahan yang peserta didik temukan secara otomatis akan menimbulkan berbagai analisis permasalahan sehingga membentuk karakter peserta didik yang kritis.

Berpikir kritis sangat penting dimiliki oleh peserta didik karena berpikir kritis dapat mengembangkan cara berpikir peserta didik. Susanto (2015: 121) mengemukakan pendapat bahwa berpikir kritis adalah suatu kegiatan melalui cara berpikir ide atau gagasan yang berhubungan dengan konsep yang diberikan atau dipaparkan. Menurut Ariani, berpikir kritis dapat mengantarkan seseorang pada tingkat pemahaman yang mendalam sehingga ia mengerti maksud dibalik ide atau suatu kejadian (Ariani, 2018).

Berdasarkan hasil observasi yang dilakukan di kelas IV A SDN 4 Kotayasa Kecamatan Sumbang Kabupaten Banyumas, kemampuan berpikir kritis peserta didik yang masih sangat rendah terutama pada materi-materi pembelajaran Bahasa Indonesia dan PPKn yang sebagian besar disebabkan karena kurangnya minat membaca peserta didik, selain itu peserta didik yang masih cenderung pasif dan kurang termotivasi untuk ingin tahu saat ada materi pelajaran yang baru diajarkan, serta peserta didik belum berani bertanya atau mengemukakan pendapat atau gagasan saat pembelajaran berlangsung. Untuk kegiatan diwaktu senggangpun seperti saat istirahat maupun jam pelajaran kosong peserta didik tidak memanfaatkan waktu untuk membaca ataupun mengunjungi perpustakaan. Walaupun sudah memiliki gedung perpustakaan dan buku perpustakaan yang sudah lengkap tetapi peserta didik tidak memiliki minat untuk membaca buku-buku tersebut. Pada situasi tersebut guru harus memiliki cara untuk membangun keterampilan berpikir kritis dan sikap gemar membaca peserta didik untuk mengembangkan potensi yang dimiliki oleh peserta didik dan mengatasi masalah yang terjadi. Guru harus memiliki inovasi dan mengembangkan model belajar dan metode yang tepat dalam menyampaikan materi pembelajaran.

Alternatif pemecahan masalah yang menjadi pilihan peneliti yaitu dengan menerapkan model pembelajaran Predict Observe Explain (POE) berbasis literasi. YingTien Wu dan Chin-Chung Tsai (2005: 113) mengemukakan Predict, Observe, Explain (POE) dilandasi oleh teori pembelajaran kontruktivisme yakni dengan menggali pengetahuan yang telah diperoleh atau yang dimiliki peserta didik sebelumnya dan 
kemudian diinterpretasikannya. Model pembelajaran ini digunakan karena memberi kesempatan pada peserta didik untuk berlatih memprediksi gejala-gejala di lingkungan dengan alasan yang logis, membuktikan kebenaran prediksi melalui percobaan serta menjelaskan temuan-temuan berdasarkan hasil pengamatannya secara ilmiah. Warsono dan Hariyanto (2013: 93) menyatakan bahwa model pembelajaran Predict Observe Explain (POE) dilandasi dari teori pembelajaran kontruktivisme yang beranggapan bahwa melalui kegiatan prediksi, observasi dan pengamatan, maka struktur kognitifnya akan terbentuk dengan baik. Model pembelajaran Predict Observe Explain (POE) berbasis literasi merupakan model pembelajaran yang menitikberatkan pada kemampuan membaca peserta didik guna menumbuhkan rasa ingin tahu yang dimilikinya sehingga peserta didik dapat memperoleh informasi atau pengetahuan baru dari teks bacaan atau literasi tersebut. Selanjutnya peserta didik dapat menerapkan model pembelajaran Predict Observe Explain (POE) dalam proses pembelajaran dengan langkah-langkah kegiatan pembelajaran yang akan dilakukan yaitu pertama guru menyiapkan kondisi kelas lalu mengulas kembali materi sebelumnya. Selanjutnya masuk pada kegiatan inti, guru memberikan informasi tujuan pembelajaran dan mengenai model Predict Observe Explain (POE) berbasis literasi yang akan digunakan dalam pembelajaran, kemudian guru melakukan apersepsi dan melakukan tanya jawab seputar materi, kemudian guru membagi teks bacaan sebagai literasi pada peserta didik guna memunculkan rasa ingin tahu dari setiap peserta didik. Melalui model pembelajaran Predict Observe Explain (POE) berbasis literasi keterampilan berpikir kritis peserta didik berkembang secara optimal dan peserta didik dilatih mengembangkan daya nalarnya dengan cara menghubungkan antar fakta yang diamati dari percobaan yang dilakukan.

Berdasarkan permasalahan dan hasil observasi yang telah dipaparkan sebelumnya, maka penulis tertarik untuk melaksanakan penelitian yang berjudul "Upaya Meningkatkan Keterampilan Berpikir Kritis dan Sikap Gemar Membaca Peserta Didik melalui Model Predict Observe Explain (POE) Berbasis Literasi pada Tema 7 Indahnya Keragaman di Negeriku di Kelas IV A SDN 4 Kotayasa". Inovasi pada penelitian dilakukan yaitu pembelajaran yang berbasis literasi sebagai media pembelajaran guna menggali rasa ingin tahu yang dimiliki oleh peserta didik, melakukan kegiatan menyimpulkan hasil prediksi dan hasil percobaan di depan kelas bertujuan untuk melatih peserta didik mengemukakan pendapatnya berdasarkan fakta yang telah diperoleh.

Perumusan masalah pada penelitian ini yaitu "Bagaimanakah model pembelajaran

Predict Observe Explain (POE) berbasis literasi dapat meningkatkan keterampilan berpikir kritis dan sikap gemar membaca peserta didik pada kelas IV A tema 7 Indahnya Keragaman di Negeriku di SDN 4 Kotayasa?”. Tujuan penelitian yang ingin dicapai adalah mengkaji secara mendalam peningkatan keterampilan berpikir kritis dan sikap gemar membaca peserta didik dengan menggunakan model pembelajaran Predict Observe Explain (POE) berbasis literasi pada kelas IVA tema 7 Indahnya Keragaman di Negeriku SDN 4 Kotayasa.

\section{METODE}

Penelitian ini merupakan penelitian tindakan kelas yang dilaksanakan di SDN 4 Kotayasa pada semester 2 Tahun Ajaran 2018/2019. Subjek penelitian adalah peserta didik kelas IVA berjumlah 26 peserta didik yang terdiri dari 12 peserta didik laki-laki dan 14 peserta didik perempuan.

Penelitian ini menggunakan model PTK Kemmis dan Mc Taggart sebagaimana dikutip oleh Jumiati (2017) terdiri dari kegiatan perencanaan, tindakan, observasi dan refleksi. Teknik pengumpulan data dalam penelitian ini dengan menggunakan teknik tes 
dan teknik non tes (observasi, angket dan dokumentasi). Alat pengumpulan data menggunakan tes uraian yang sesuai dengan indikator keterampilan berpikir kritis, lembar observasi gemar membaca peserta didik, lembar observasi aktivitas peserta didik, dan lembar observasi aktivitas guru, skala sikap gemar membaca peserta didik serta dokumentasi.

\section{HASIL DAN PEMBAHASAN \\ Hasil}

Hasil penelitian ini menemukan bahwa terdapat peningkatan keterampilan berpikir kritis dan sikap gemar membaca peserta didik melalui model pembelajaran Predict Observe Explain (POE) berbasis literasi. Hal tersebut dibuktikan dengan meningkatnya rasa ingin tahu peserta didik melalui teks literasi yang diberikan oleh guru. Sehingga minat peserta didik dalam membaca pun meningkat. Hal tersebut membuat pembelajaran menjadi aktif dan berkesan bagi peserta didik. Untuk mengukur keterampilan berpikir kritis, peserta didik diberikan soal tes tertulis uraian dengan jumlah soal 5 butir soal uraian yang dibatasi waktu dalam setiap pengerjaan soalnya yaitu 3 menit. Untuk menjawab soal tersebut peserta didik harus mengumpulkan data atau informasi dari teks literasi ataupun sumber bacaan lain yang diberikan oleh guru guna menambah wawasan dan pengetahuan peserta didik. Soal uraian tersebut dibuat berdasarkan indikator keterampilan berpikir kritis. Peningkatan hasil keterampilan berpikir kritis dapat dilihat pada tabel 1 dibawah ini:

Tabel 1. Peningkatan keterampilan berpikir kritis

\section{Rata-rata}

No

Indikator Keterampilan

Siklus I

Siklus II Berpikir Kritis

\begin{tabular}{clcc}
\hline 1. & Memberikan penjelasan sederhana & 2,05 & 3,85 \\
\hline 2. & Membangun keterampilan dasar & 4 & 3,7 \\
\hline 3. & Membuat inverensi/ menyimpulkan & 2,9 & 2,9 \\
\hline 4. & Memberikan penjelasan lebih lanjut & 2,4 & 3,25 \\
\hline 5. & Mengatur strategi dan taktik & 2,35 & 4,35 \\
\hline JUMLAH & $\mathbf{1 3 , 7}$ & $\mathbf{1 8}$ \\
\hline RATA-RATA & $\mathbf{2 , 7}$ & $\mathbf{3 , 6}$ \\
\hline KRITERIA & Kurang Baik & Baik \\
\hline
\end{tabular}

Berdasarkan tabel 1 dari kelima indikator tersebut yang mengalami peningkatan secara signifikan adalah indikator mengatur strategi dan taktik, hal tersebut dikarenakan peserta didik dapat menganalisis sikapnya terhadap keadaan yang disajikan dalam soal. Sedangkan indikator yang mengalami penurunan adalah indikator membangun keterampilan dasar. Hal tersebut dikarenakan peserta didik kurang teliti dalam membaca teks literasi dan soal yang diberikan oleh guru.

Hasil sikap gemar membaca peserta didik diperoleh dari pengamatan hasil observasi sikap gemar membaca peserta didik, aktivitas peserta didik saat proses pembelajaran di dalam kelas dan hasil angket/ skala sikap gemar membaca peserta didik. Skala sikap gemar membaca diberikan kepada peserta didik pada pertemuan kedua atau diakhir siklus. Sikap gemar membaca peserta didik mengalami peningkatan setelah menggunakan model pembelajaran Predict Observe Explain (POE) berbasis literasi siklus I ke siklus II. Hasil presentase nilai rata-rata hasil gemar 
membaca berkaitan dengan Tema 7 Indahnya Keragaman di Negeriku di kelas IV A SDN 4 Kotayasa dapat dilihat pada tabel 2 berikut.

Tabel 2. Skala Sikap Gemar Membaca Peserta Didik

\begin{tabular}{|c|c|c|c|c|}
\hline No. & Indikator & Pernyataan & Siklus I & Siklus II \\
\hline \multirow[t]{5}{*}{1.} & \multirow{5}{*}{$\begin{array}{l}\text { Membaca } \\
\text { buku dan } \\
\text { tulisan yang } \\
\text { terkait dengan } \\
\text { mata pelajaran }\end{array}$} & $\begin{array}{l}\text { Melaksanakan perintah guru ketika } \\
\text { diperintahkan untuk membaca bacaan yang } \\
\text { terkait dengan materi pelajaran. }\end{array}$ & 4,8 & 4,8 \\
\hline & & $\begin{array}{l}\text { Membaca materi pelajaran ketika di rumah } \\
\text { adalah kegiatan yang biasa dilakukan setiap } \\
\text { hari. }\end{array}$ & 4,3 & 4,3 \\
\hline & & $\begin{array}{l}\text { Bertanya kepada guru apabila ada materi } \\
\text { yang sudah diajarkan tetapi belum jelas. }\end{array}$ & 3,3 & 4,2 \\
\hline & & 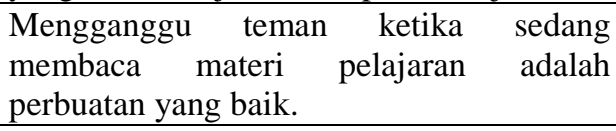 & 3,7 & 4,2 \\
\hline & & $\begin{array}{l}\text { Menonton film di rumah lebih disukai dari } \\
\text { pada membaca materi pelajaran. }\end{array}$ & 2,9 & 4,2 \\
\hline \multirow[t]{2}{*}{2.} & $\begin{array}{l}\text { Mencari bahan } \\
\text { bacaan dari } \\
\text { sumber lain }\end{array}$ & $\begin{array}{l}\text { Suka berkunjung ke perpustakaan untuk } \\
\text { membaca buku pelajaran adalah perbuatan } \\
\text { yang perlu ditiru. }\end{array}$ & 4,8 & 5,1 \\
\hline & & $\begin{array}{l}\text { Membuat gaduh ketika diperpustakaan } \\
\text { sekolah. }\end{array}$ & 3,6 & 5,2 \\
\hline 3. & $\begin{array}{l}\text { Membaca } \\
\text { tulisan tentang } \\
\text { alam, sosial, } \\
\text { budaya, seni } \\
\text { dan teknologi }\end{array}$ & $\begin{array}{l}\text { Lebih suka bermain daripada membaca } \\
\text { buku atau tulisan tentang alam, sosial, } \\
\text { budaya, seni, dan teknologi yang terkait } \\
\text { dengan materi pelajaran. }\end{array}$ & 3 & 4,6 \\
\hline \multicolumn{2}{|c|}{ Jumlah } & & 30,4 & 36,6 \\
\hline \multicolumn{2}{|c|}{ Rata-rata } & & 3,8 & 4,5 \\
\hline \multicolumn{2}{|c|}{ Kriteria } & & Baik & $\begin{array}{c}\text { Sangat } \\
\text { Baik }\end{array}$ \\
\hline
\end{tabular}

Hasil sikap gemar membaca peserta didik berdasarkan tabel 2 menunjukkan bahwa adanya peningkatan nilai rata-rata dari siklus I ke siklus II melalui model pembelajaran Predict Observe Explain (POE) berbasis literasi pada siklus I dapat dikategorikan ke dalam kriteria baik dan pada siklus II terjadi peningkatan dengan kriteria gemar membaca sangat baik. Hal tersebut diperkuat dengan hasil observasi sikap gemar membaca peserta didik kelas IV A SDN 4 Kotayasa dapat dilihat pada tabel 3 berikut.

Tabel 3. Sikap gemar membaca peserta didik kelas IV A SDN 4 Kotayasa

\begin{tabular}{clcccc}
\hline No. & \multicolumn{1}{c}{ Pernyataan } & Siklus I & Siklus II & Jumlah & $\begin{array}{c}\text { Rata- } \\
\text { rata }\end{array}$ \\
\hline 1. & $\begin{array}{l}\text { Membaca buku dan tulisan yang } \\
\text { terkait dengan mata pelajaran }\end{array}$ & 3,7 & 4,5 & 8,2 & 4,1 \\
\hline $\begin{array}{l}\text { Mencari bahan bacaan dari } \\
\text { sumber lain }\end{array}$ & 3,5 & 4,2 & 7,7 & 3,8 \\
\hline $\begin{array}{l}\text { Membaca tulisan tentang alam, } \\
\text { sosial, budaya, seni dan } \\
\text { teknologi }\end{array}$ & 3,5 & 4,3 & 7,8 & 3,9 \\
\hline Jumlah & 10,7 & 13 & 23,7 & 11,8 \\
\hline Rata-rata keseluruhan & 3,5 & 4,3 & 3,9 \\
\hline Kriteria & Baik & $\begin{array}{l}\text { Sangat } \\
\text { Baik }\end{array}$ & \multicolumn{3}{c}{ Baik } \\
\hline
\end{tabular}


Hasil observasi sikap gemar membaca peserta didik berdasarkan tabel 3 menunjukkan bahwa adanya peningkatan rata-rata dari siklus I ke siklus II melalui model pembelajaran Predict Observe Explain (POE) berbasis literasi. Rata-rata hasil observasi sikap gemar membaca peserta didik diperoleh setelah melaksanakan pembelajaran menggunakan model pembelajaran Predict Observe Explain (POE) berbasis literasi, pada siklus I jumlah rata-rata yang diperoleh adalah 3,5 dengan kriteria baik, sedangkan pada siklus II mengalami peningkatan jumlah rata-rata yaitu 4,3 dengan kriteria sangat baik. Dari kedua siklus tersebut diperoleh rata-rata keseluruhan hasil observasi sikap gemar membaca peserta didik kelas IV A SDN 4 Kotayasa adalah 3,9 dengan kriteria baik. Hal tersebut dikarenakan peserta didik merasa terpacu dan ingin tahu mengenai permasalahan yang peserta didik baca. Sehingga peserta didik memiliki usaha untuk mencari informasi sebanyak dan selengkap mungkin untuk dapat menjawab soal keterampilan berpikir kritis maupun permasalahan yang diajukan oleh guru.

\section{Pembahasan}

\section{1) Peningkatan Keterampilan Berpikir Kritis Peserta Didik}

Pada saat Penelitian Tindakan Kelas (PTK) keterampilan berpikir kritis peserta didik diukur dengan menggunakan tes uraian yang disesuaikan dengan indikator keterampilan berpikir kritis secara individu yang diberikan oleh guru pada setiap pertemuan. Ennis dalam Kuswana (2011: 19) menjelaskan bahwa berpikir kritis merupakan berpikir wajar dan reflektif yang fokus dalam menentukan apa yang harus dipercaya atau dilakukan. Selain itu Ahmad Rindhani dalam Tutus Rani A (2018: 52) menyatakan bahwa berpikir kritis adalah sebuah proses terorganisasi yang memungkinkan peserta didik mengevaluasi bukti, asumsi, logika, dan bahasa yang mendasari pernyataan orang lain. Peningkatan keterampilan berpikir kritis kelas IV A SDN 4 Kotayasa siklus I dan siklus II dapat dilihat pada gambar 1 berikut.

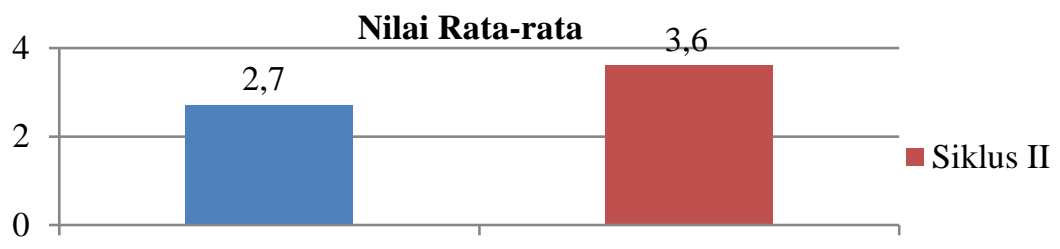

\section{Gambar 1 Diagram Hasil Keterampilan Berpikir Kritis}

Berdasarkan diagram hasil keterampilan berpikir kritis peserta didik pada siklus I memperoleh rata-rata sebesar 2,7 dengan kriteria kurang baik, sedangkan pada siklus II meningkat dengan rata-rata keterampilan berpikir kritis peserta didik sebesar 3,6 dengan kriteria baik. Keterampilan berpikir kritis merupakan implementasi awal dari ide peserta didik dalam menemukan konsep. Peserta didik diharapkan mampu mengoptimalkan keterampilan berpikir kritis setelah menemukan konsep yang dituju. Tilaar dkk (2011: 17) menyebutkan pentingnya berpikir kritis antara lain : 1) Mengembangkan berpikir kritis dalam pendidikan berarti memberikan penghargaan kepada peserta didik. 2) Berpikir kritis merupakan tujuan yang ideal didalam pendidikan karena mempersiapkan peserta didik untuk kehidupan kedewasaannya. 3) Pengembangan berpikir kritis dalam proses pendidikan merupakan suatu cita-cita tradisional seperti apa yang ingin dicapai melalui pelajaran ilmu-ilmu eksak kelamaan serta mata-mata pelajaran lainnya yang secara tradisional dianggap dapat mengembangkan berpikir kritis. 4) Berpikir kritis merupakan suatu hal yang sangat dibutuhkan dalam kehidupan demokratis. 
Keterampilan berpikir kritis merupakan keterampilan yang bukan melekat pada diri manusia sejak lahir. Keterampilan berpikir kritis harus dilatih dalam proses pembelajaran. Keterampilan berpikir kritis peserta didik dapat diukur melalui indikator keterampilan berpikir kritis. Berikut indikator keterampilan berpikir kritis menurut Ennis dalam Susanto (2015: 125) sebagai berikut: 1) Memberikan penjelasan sederhana, 2) Membangun keterampilan dasar, 3) Menyimpulkan, 4) Memberikan penjelasan lebih lanjut, dan 5) Mengatur strategi dan taktik. Lima indikator tersebut saling berkaitan jika diimplementasikan dalam pembelajaran tematik untuk mengetahui keterampilan berpikir kritis peserta didik, sehingga kelima indikator tersebut digunakan dalam penelitian ini.

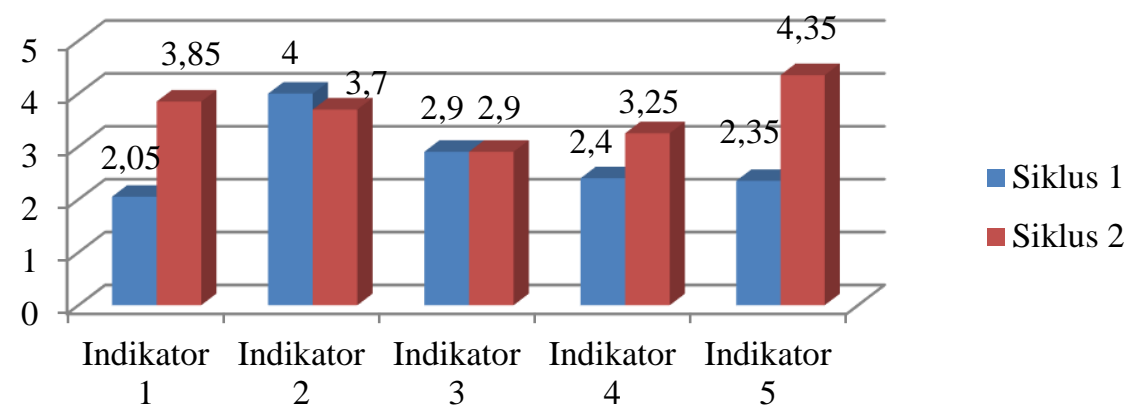

Gambar 2 Diagram Nilai Indikator Tes Keterampilan Berpikir Kritis Peserta Didik Kelas IV A SDN 4 Kotayasa

Berdasarkan diagram nilai indikator tes keterampilan berpikir kritis peserta didik kelas IV A SDN 4 Kotayasa pada siklus I, Indikator 1 yaitu memberikan penjelasan sederhana, pada siklus I diperoleh skor rata-rata yaitu 2,05 dengan kriteria tidak baik dan siklus II diperoleh rata-rata yaitu 3,85 dengan kriteria baik. Hasil tes keterampilan berikir kritis indikator 2 yaitu membangun keterampilan dasar, pada siklus I diperoleh skor ratarata yaitu 4 dengan kriteria baik dan mengalami penurunan angka yang tidak cukup jauh pada siklus II yaitu 3,7 dengan golongan kriteria yang masih baik. Hasil tes keterampilan berpikir kritis indikator 3 yaitu membuat intervensi / menyimpulkan, pada siklus I diperoleh skor rata-rata yaitu 2,9 dengan kriteria kurang baik dan mengalami hal yang sama pada siklus II dengan prolehan skor rata-rata yaitu 2,9 dan kriterianyapun kurang baik. Hasil tes keterampilan berpikir kritis indikator 4 yaitu memberikan penjelasan lebih lanjut, pada siklus I diperoleh skor rata-rata yaitu 2,4 dengan kriteria tidak baik dan mengalami peningkatan skor rata-rata pada siklus II yaitu 3,25 dengan kriteria kurang baik. Hasil tes keterampilan berpikir kritis indikator 5 yaitu mengatur strategi dan taktik, pada siklus I diperoleh skor rata-rata yaitu 2,35 dengan kriteria tidak baik dan mengalami peningkatan skor rata-rata pada siklus II yaitu 4,35 dengan kriteria sangat baik.

\section{2) Peningkatan Sikap Gemar Membaca Peserta Didik}

Pada saat Penelitian Tindakan Kelas (PTK) sikap gemar membaca diukur menggunakan lembar skala sikap gemar membaca peserta didik dan lembar observasi sikap gemar membaca peserta didik secara individu yang diberikan oleh gurupada siklus I pertemuan 2 dan siklus II pertemuan 2. Prasetyono (2008: 22) membaca merupakan serangkaian kegiatan pikiran yang dilakukan dengan penuh perhatian untuk memahami suatu informasi melalui indra penglihatan dalam bentuk simbol-simbol yang rumit, yang disusun sedemikian rupa sehingga mempunyai arti dan makna. Berdasarkan pendapat ahli tersebut, peneliti menyimpulkan bahwa gemar membaca dapat diartikan kesukaan untuk memahami dan memaknai suatu bacaan. Prasetyono (2008: 14) mengemukakan bahwa untuk membuat aktivitas membaca menjadi suatu kegemaran, hal yang harus dimiliki seseorang adalah minat baca yang tinggi. Pada penelitian ini, skala sikap gemar membaca diberikan kepada peserta didik pada pertemuan kedua atau diakhir siklus. Sikap gemar 
membaca peserta didik mengalami peningkatan setelah menggunakan model pembelajaran Predict Observe Explain (POE) berbasis literasi siklus I ke siklus II.

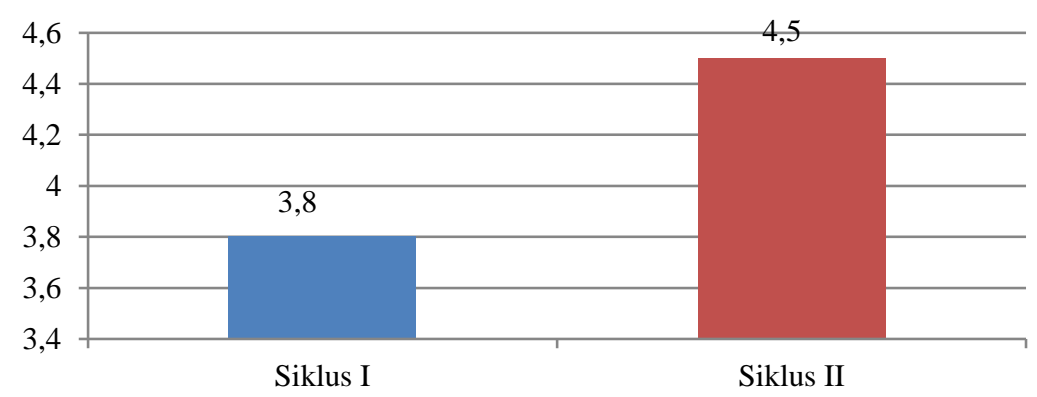

Gambar 3 Histogram Peningkatan Skala Sikap Gemar Membaca Peserta Didik Kelas IV A SDN 4 Kotayasa

Berdasarkan gambar 3 menunjukkan bahwa adanya peningkatan nilai rata-rata dari siklus I ke siklus II melalui model pembelajaran Predict Observe Explain (POE) berbasis literasi pada siklus I memperoleh rata-rata 3,8 dan dikategorikan ke dalam kriteria baik dan pada siklus II terjadi peningkatan memperoleh rata-rata 4,5 dengan kriteria gemar membaca sangat baik. Hal tersebut diperkuat dengan hasil observasi sikap gemar membaca peserta didik kelas IV A SDN 4 Kotayasa. Hal tersebut diperkuat dengan hasil observasi sikap gemar membaca peserta didik yang mengalami peningkatan rata-rata dari siklus I ke siklus II melalui model pembelajaran Predict Observe Explain (POE) berbasis literasi. Rata-rata hasil observasi sikap gemar membaca peserta didik diperoleh setelah melaksanakan pembelajaran menggunakan model pembelajaran Predict Observe Explain (POE) berbasis literasi, pada siklus I jumlah rata-rata yang diperoleh adalah 3,5 dengan kriteria baik, sedangkan pada siklus II mengalami peningkatan jumlah rata-rata yaitu 4,3 dengan kriteria sangat baik.

Peningkatan tersebut terjadi setelah adanya pembelajaran menggunakan model pembelajaran Predict Observe Explain (POE) berbasis literasi. Model pembelajaran Predict Observe Explain (POE) berbasis literasi merupakan model pembelajaran yang membelajarkan peserta didik dengan membuat prediksi atas suatu kejadian berdasarkan konsepsi mereka sendiri, kemudian mengobservasi kejadian tersebut secara nyata, dan yang terakhir menjelaskan hasil pengamatan mereka serta menjelaskan ketidaksesuaian prediksi mereka dengan keadaan yang sebenarnya Widyaningrun (2013: 103). Model ini memberikan kesempatan kepada peserta didik untuk mengemukakan pengetahuan awal mereka terkait teks literasi ataupun materi yang diberikan, adanya kerjasama antar peserta didik selama diskusi berlangsung, adanya tukar pendapat antar peserta didik satu dengan yang lain, adanya perubahan konseptual pada pengetahuan yang dimiliki oleh peserta didik. Hal tersebut sesuai dengan pendapat Arifin Muslim dan Badarudin (2017: 23) yang menjelaskan bahwa dengan menggunakan model pembelajaran Predict Observe Explain (POE) guru menggali pemahaman peserta didik dengan cara meminta peserta didik untuk melaksanakan tiga tugas utama, yaitu membuat rancangan atau dugaan (Predict), melakukan pengamatan (Observe), dan melakukan analisis atau penjelasan (Explain). Dengan melaksanakan tiga tugas utama tersebut peserta didik akan dituntut untuk menemukan pengetahuan sendiri dengan melakukan pengamatan langsung terhadap suatu persoalan, kemudian dibuktikan dengan melakukan pengamatan dan percobaan untuk dapat menemukan kebenaran dari dugaan awal dalam bentuk penjelasan dari teks literasi maupun bahan bacaan yang sudah peserta didik baca.

Hal tersebut sesuai dengan teori yang dikemukakan oleh Prasetyono (2008: 22) menjelaskan bahwa membaca merupakan sarana hiburan dan sarana menambah wawasan dan pengetahuan, dengan membaca seseorang dapat merangsang otaknya untuk berfikir kreatif dan sistematis, memperluas dan memperkaya wawasan, serta menimbulkan kepribadian yang unggul dan kompetitif. Peningkatan gemar membaca yang lebih baik 
disebabkan karena sikap dalam membaca peserta didik mulai tumbuh dan terbiasa, sehingga ketika dalam proses pembelajaran melalui model pembelajaran Predict Observe Explain (POE) berbasis literasi peserta didik dapat mengerjakan tugas yang diberikan guru dengan baik. Wawasan dan pengetahuan dapat ditambah dengan kegiatan membaca. Selain itu, dengan membaca seseorang akan berkembang daya kreatifitasnya. Pola pikir kreatif akan terwujud apabila seseorang mengembangkan pola pikir serta mampu merespon lingkungan sekitar dengan cepat dan hal tersebut dilatih dengan kegiatan gemar membaca. Maka dari itu perlu adanya tindakan terhadap peserta didik yang kurang gemar membaca.

\section{PENUTUP}

Hasil Penelitian Tindakan Kelas (PTK) yang telah dilaksanakan selama dua sikus dalam upaya meningkatkan keterampilan berpikir kritis dan sikap gemar membaca peserta didik melalui model pembelajaran Predict Observe Explain (POE) berbasis literasi pada kelas IV A SDN 4 Kotayasa, dapat disimpulkan sebagai berikut:

1. Keterampilan berpikir kritis peserta didik dengan menggunakan model pembelajaran Predict Observe Explain (POE) berbasis literasi siklus I ke siklus II mengalami peningkatan. Jumlah skor rata-rata kelas pada siklus I mencapai 2,7 dengan kriteria kurang baik, meningkat pada siklus II dengan jumlah skor rata-rata peserta didik mencapai 3,6 dengan kriteria baik. Keterampilan berpikir kritis peserta didik dikatakan meningkat dari siklus I ke siklus II.

2. Sikap gemar membaca peserta didik dengan menggunakan model pembelajaran Predict Observe Explain (POE) berbasis literasi dari siklus I ke siklus II mengalami peningkatan. Jumlah skor rata-rata kelas pada siklus I mencapai 3,8 dengan kriteria baik, meningkat pada siklus II dengan jumlah skor rata-rata mencapai 4,5 dengan kriteria sangat baik. Hal tersebut juga dibuktikan dengan hasil observasi sikap gemar membaca peserta didik pada siklus I memperoleh rata-rata keseluruhan yaitu 3,5 dengan kriteria baik dan meningkat pada siklus II yang memperoleh rata-rata keseluruhan yaitu 4,3 dengan kriteria sangat baik. Siklus I dan siklus II tersebut menghasilkan rata-rata keseluruhan hasil observasi sikap gemar membaca peserta didik adalah 3,9 dengan kriteria baik. Sikap gemar membaca peserta didik dikatakan meningkat dari siklus I ke siklus II.

Berdasarkan hasil penelitian yang telah dilaksanakan di kelas IV A SDN 4

Kotayasa, maka diajukan saran yang dapat dijadikan masukan dan pertimbangan untuk melakukan penelitian selanjutnya yang lebih baik. Saran tersebut meliputi:

1. Guru harus dapat menyiapkan perencanaan dengan matang agar penerapan model pembelajaran Predict Observe Explain (POE) berbasis literasi dapat berjalan dengan baik.

2. Guru harus lebih kreatif dan inovatif dalam kegiatan pembelajaran, dari kegiatan memprediksi, guru harus membuat peserta didik terpancing untuk ingin tahu dengan menampilkan permasalahan yang guru buat, membuat pengamatan yang menarik dengan menggunakan alat dan bahan yang mudah didapat.

3. Apabila dilihat dari tes keterampilan berpikir kritis peserta didik, guru perlu membiasakan peserta didik dilatih mengerjakan soal-soal bentuk uraian yang memerlukan proses berpikir tingkat tinggi.

4. Guru sebagai pelaksana kegiatan pembelajaran dalam menerapkan model pembelajaran Predict Observe Explain (POE) berbasis literasi harus dapat memberikan selingan permainan atau ice breaking agar peserta didik tidak mudah bosan dengan pembelajaran yang banyak mengandung unsur bacaan di dalamnya. 
5. Hasil penelitian ini dapat dilanjutkan dan dikembangkan lebih mendalam lagi oleh pembaca dengan menggunakan penelitian lain yang sejenis atau yang dianggap lebih baik, tentunya dengan model lain dan pembelajaran lainnya. Hal tersebut dilakukan dalam rangka mencari solusi terbaik dalam pembelajaran tematik agar lebih baik lagi.

\section{DAFTAR PUSTAKA}

Ariani, D. N. (2018). Pengaruh Model Pembelajaran Berbasis Masalah Dengan Pendekatan Saintifik Terhadap Kemampuan Berfikir Kritis Matematis Mahasiswa/I PGMI. Muallimuna: Jurnal Madrasah Ibtidaiyah, 3(2), 108-115.

Jumiati, J. (2017). Penerapan Metode Karya Wisata pada Konsep Dasar IPA MI/SD Materi Perkembangbiakan untuk Meningkatkan Motivasi Belajar Mahasiswa PGMI. Muallimuna: Jurnal Madrasah Ibtidaiyah, 2(2), 19-27.

Kuswana, W. S. (2011). Taksonomi Berpikir. Bandung: PT Remaja Rosdakarya.

Muslim, A., \& Badarudin. (2017). Penggunaan Model POE (Prediction Observaton Explanation) pada Pembelajaran IPA untuk Meningkatkan Hasil Belajar Siswa di Kelas IV MI Muhammadiyah Beji. Jurnal Seminar Nasional.

Prasetyono, D.S. (2008). Rahasia Mengajarkan Gemar Membaca Pada Anak Sejak Dini. Jogjakarta: Think.

Rianti, Maya., Dkk. (2015). Pendidikan 18 Karakter Bangsa SD/MI-SMP/MTs: Gemar Membaca: Mustika Cendekia Negeri.

Susanto,A. (2015). Teori Belajar dan Pembelajaran di Sekolah Dasar. Jakarta: Kencana Prenada Media Grup.

Tilaar, H.A.R., Paat, J.Ph., dan Paat, L. (2011). Pedagogik Kritis. Jakarta: Rineka Cipta. Warsono \& Hariyanto. (2013). Pembelajaran Aktif. Bandung: PT Remaja Rosdakarya.

Widyaningrum, R., Sarwanto., \& Karyanto, P. (2013). Pengembangan Modul Berorientasi POE (Predict Observe Explain) Berwawasan Lingkungan pada Materi Pencemaran untuk Meningkatkan Hasil Belajar Peserta didik. Jurnal Bioedukasi.1(6), 100-117.

Wu, Y.T \& Tsai, C.C. (2005). Effect of Constructivistoriented Instruction on Elementary School Student Cognitive Structures. Journal of Biological Education. 39(3), 113-119. 